The BDJ News section accepts items that include general news, latest research and diary events that interest our readers. Press releases or articles may be edited, and should include a colour photograph if possible. Please direct your correspondence to the News Editor, Liane Voisey at the BDJ, 64 Wimpole Street WIG 8YS or by e-mail to bdj@bda-dentistry.org.uk

\section{Honours for dentists}

The Queen's birthday honours list includes four dentists who have made a significant contribution to the dental industry.

Tom Macadam OBE was recognised for services to dentistry and to the GDC, from which he retired last year. One of the longest serving members of the Council, he represented Scotland for 25 years. Tom Macadam rose to the position of deputy to the President.

Colin Lee MBE is a holder of the BDA's Roll of Distinction. His honour was for services to dental technology, especially with regards to education and training. Colin Lee also served on the Nuffield Inquiry, which led to the current moves towards a greater role for Professionals Complementary to Dentistry (PCD's).

James Partridge OBE is the founder and Chief Executive of Changing Faces, based in London. His honour was for services to disabled people, especially as founder and chief executive of Changing Faces and director of the Centre for Appearance and Disfigurement Research, at the University of the West of England. James Partridge is recognised for raising the profile of this particular disability.

Alan Owen MBE is a GDP with his own practice in Lerwick, the capital of the Shetland Isles. He is being awarded the MBE for services to dental health in Shetland.

The BDJ offers its sincere congratulations to them all.

\section{GDC election time}

The new 29-member GDC is just around the corner and election time will soon be upon us.

For the first time, all the dental members of Council will be elected by the profession.

The GDC will be opening the nominations for the election of the 15 dentist and 4 PCD members very shortly. Voting will taking place in the Autumn.

The $B D J$ will be publishing further announcements. Also watch the GDC website for election updates.

\section{Accolade for popular dentist}

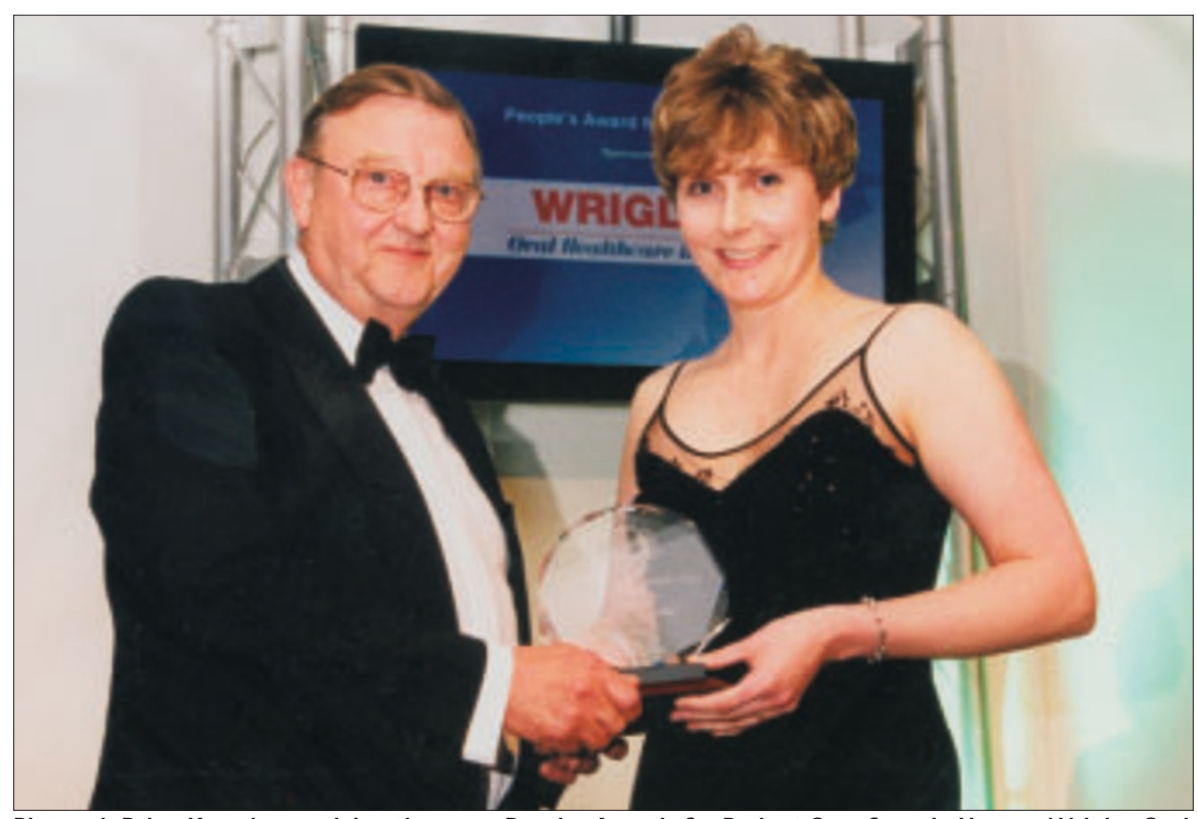

Pictured: Brian Knowles receiving the 2002 Peoples Awards for Patient Care from Jo Hartop, Wrigley Oral Healthcare in Action Manager.

Wolverhampton practitioner Dr Brian Knowles is the winner of the People's Award for Patient Care, in which patients nominate the dentist they feel most deserves the title. The award, sponsored by Wrigley Oral Healthcare in Action, led to hundreds of letters and calls from patients around the country eager to praise their dentist. Along with other winners, Brian Knowles received his prize at the Dental Awards 2002.

Dr Knowles has practised at Richmond House Dental Surgery for 40 years, and was entered by his practice staff for the award without his knowledge, and only found out when he was invited to the ceremony. His award entry was accompanied by over 30 letters of appreciation from patients. Dr Knowles is semi-retired now but still rings or calls into the surgery almost every day to check on staff and patients.

\section{Young dentists, the good and the bad}

A BDA survey has indicated that nine out of ten young dentists were pleased that they had chosen a career in dentistry with an even higher proportion stating that they were pleased with their chosen area of dentistry. The BDA Young Dentist Survey (2001/2002), compiled by the BDA Policy Directorate, also found that three in five young dentists are interested in being actively involved in vocational training as an advisor or trainer.

The majority of dentists responding to the survey had completed their vocational training period and did so directly after graduating from dental school. The experience gained in this year, in addition to dental experience generally, appears to be crucial in developing individual competency and confidence for undertaking a range of dental procedures from routine extractions to cast restorations.

Student debt provides a burden for many young dentists under the age of 30. Three quarters of young dentists were in debt when they graduated, with one third of these graduating with levels of debt in excess of $£ 10,000$. Almost one in five young dentists felt that their level of student debt had influenced their career choice. It remains to be seen whether this proportion increases as a result of introducing tuition fees. 


\section{NHS pay deal}

The announcement that NHS staff will be offered a 10 per cent three-year pay deal alongside reforms to their pay systems has received a cautious welcome from dentists.

News of the pay deal came as Health Secretary Alan Milburn unveiled a new NHS consultants' contract. It is already a crucial time for dentists as they await government proposals on ways to modernise NHS dentistry to safeguard its future. Warren Jones, chairman of the Central Committee for Hospital Dental Services at the BDA, says that the new contract should provide a good working framework for consultants within the NHS. He says that it will now be down to the Government to ensure that the NHS and those working within it continue to be supported.

\section{To the 'manor born'}

Actress and High Sheriff of Surrey Penelope Keith visited East Surrey Hospital recently where she met with voluntary helpers and officially opened the new Access Unit (DAC) which has been expanded to provide more dental services.

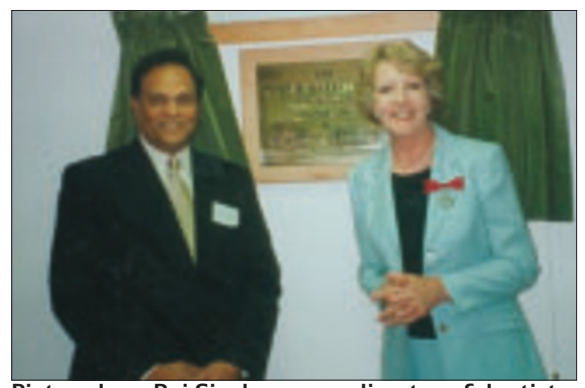

Pictured are Raj Sivakumaran, director of dentistry at Surrey \& Sussex Healthcare NHS Trust with Penelope Keith OBE, at the opening ceremony of the Dental Access Centre at East Surrey Hospital.

\section{Two reasons to celebrate!}

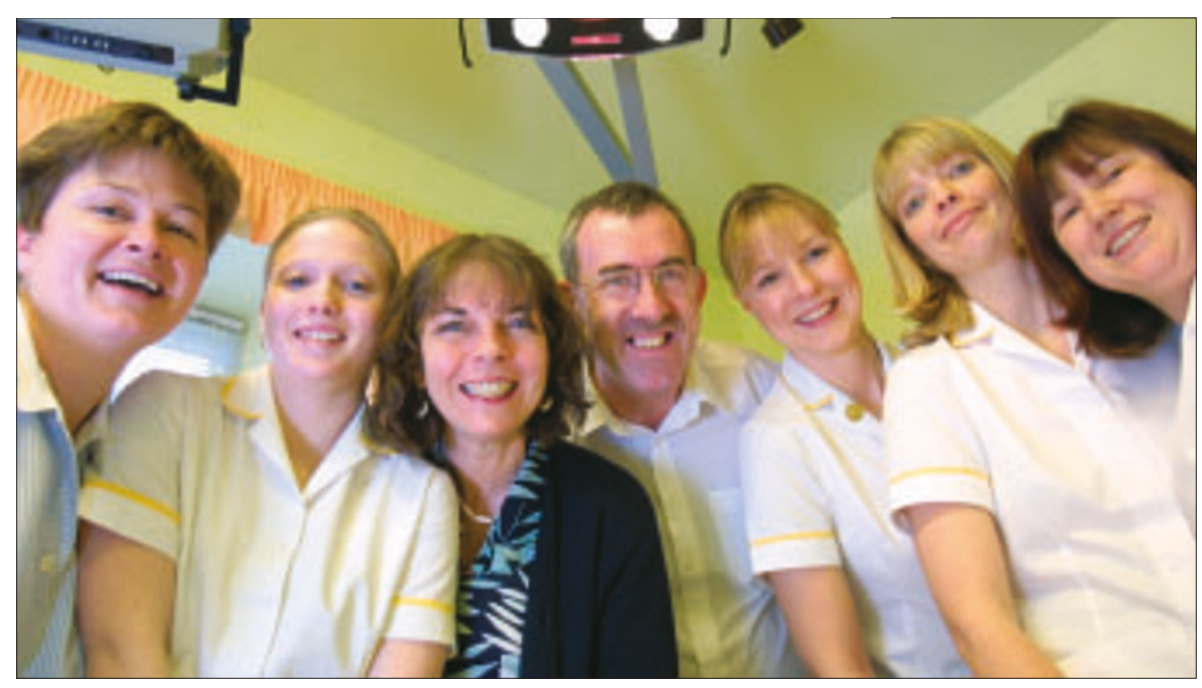

Russell and Janet Evans Dental Care of Kidlington, Oxford (pictured above), achieved a double whammy recently. The practice not only reached its 20th birthday but was recognised with the prestigious 'Investor in People' award. A party was thrown for staff and patients to get together (pictured above) to mark the double celebration.

\section{Mercury hygiene}

A recent news item in the $B D J$ on the dangers of long-term exposure to mercury $(B D J$ $2002 ; 192: 610)$ provoked feedback from practices wanting to know more about how to test their staff's exposure to the chemical.

The BDA recommend regular biological monitoring, a method of screening which can done via post (by urinanalysis). A number of companies offer this service but the BDA recommend the UK Mercury Screening Service who charge approximately £23.50 per sample. Generally speaking, dental nurses tend to have higher readings than dentists because the nurses make up the amalgam.

Female dental workers who are planning a family will want to be assured that they are not being over-exposed to mercury vapour so biological monitoring is particularly relevant to them.

The frequency of monitoring should reflect the use of mercury within the practice some practices may use it on a daily basis and others may use it less frequently. The use of capsules can also minimise the risk of exposure, however, these can be faulty and the MDA recently issued a Safety Notice regarding the 'leaking' of capsules, so it is important to be aware of the potential for this to occur. .

For advice about mercury hygiene contact BDA Shop for a copy of the A3 Advice Sheet, 'Health and Safety Law in Dentistry' by calling 0207563 4555. For urinanalysis contact the UK Mercury Screening Service on 01142900521 


\section{Getting back to practice?}

There has never been a more important time to keep in touch with dentistry even if you have been out of clinical practice for some time.

The new legislation on mandatory CPD introduced in January means that keeping up to date is an essential requirement for 'getting back to practice. That is why the 'Keeping in Touch with Dentistry Scheme' (KITS) was set up, to encourage dentists to keep in contact with dental practice and continue professional development during career breaks. A network of retaining and retraining advisors (RRA's) was also appointed - these are listed below. The scheme was launched by Health Minister Hazel Blears at BDA headquarters in London. An RRA can inform you of suitable training courses or a personal education plan before you return to work.

\section{Christine Osborne RRA FOR KENT, SURREY AND SUSSEX \\ Christine Osborne has been in general practice since she qualified from GKT Dental Institute and owns her own practice in West Byfleet, Surrey. \\ Juliana Henking RRA FOR LONDON}

Juliana works as a senior dental officer treating patients with Special Needs. She is also a parttime clinical demonstrator in periodontology at GKT Dental Institute.

Julia Densem RRA FOR SHEFFIELD

Julia was forced to retire from clinical practice in 2000 due to a severe latex allergy. Julia now acts as a Local Adviser for Dental Protection Ltd.

Andrew Collier RRA FOR LEEDS

Andrew has worked as a GDP for 20 years and as a part-time clinical teacher at Leeds Dental Hospital where he is also the organiser for the undergraduate course in General Dental Practice. Jane Moore RRA FOR BRISTOL Jane is retired as a GDP in an NHS practice. She set up (and still runs) the dental nurse training course in Barnstaple, having been a NEBDN (National Examining Board for Dental Nurses) examiner since 1987.

Nicola Spillane RRA FOR OXFORD

Nicola works in a practice in Thatcham, Berkshire. In 1999, Nicola founded and was the inaugural chairman of BDA Berkshire Young Dentists Group.

To contact an RRA listed above and for more details about the 'Keeping in Touch' scheme contact Lee Surry. Telephone 020 7905 1227, Fax 02079051224 and e-mail Isurry@nccped.co.uk The website www.nccped.co.uk is also useful.
Michael Norton RRA FOR WESSEX Mike has worked in general dental practice and is currently a postgraduate dental tutor in Southampton and is a dental practice adviser for Hampshire and Isle of Wight Health Authority.

Helen Sayer RRA FOR LIVERPOOL

Since qualifying from Liverpool University and completing a vocational training course in Brighton, Helen has had two career breaks to have two daughters and is well aware of the challenges involved in balancing domestic and professional commitments.

Nick Ward RRA FOR MANCHESTER

Nick has been in general dental practice since qualifying. He has been involved with the Faculty Of GDPs and supports their aims of raising the standards and status of primary dental care.

Jane Davies-Slowik RRA FOR BIRMINGHAM

Jane works in Wolverhampton as clinical director for the Community and Personal Dental Services. Jane has taken two career breaks. Richard Seppings RRA FOR CAMBRIDGE

Richard started his own practice, with another dentist, and that partnership continued until 1999.

Richard has been dental practice adviser for Lincolnshire Health Authority for the last year.

Malcolm Smith RRA FOR NEWCASTLE Malcolm has spent nearly thirty years as a GDP in NHS dental practice. In addition he is dental adviser to Tees Health Authority (now Tees Shared Services) and vocational training adviser for the Cumbria \&t South Durham Scheme. 
DIARY

September 2002

European Association for Cranio-

Maxillofacial Congress 2002

Date: 03.09.02-07.09.02

Venue: Münster, Germany

Contact: Ariane Minarik, ABC Congress

Service, Arberstr. 18, D-81679,

München.

Tel: +49 (0)189 23115015

Fax: +49 (0)189 263167

E-mail:ABC-Congr-Service@t-online.de

BDA/MDDUS 2002 Scottish Young Dentist Conference

Date: 06.09.02-07.09.02

Venue: Dunblane Hilton Hydro

Contact: Fiona Angus, Deputy Scottish

Secretary, 4 Atholl Place, Perth

PH1 5ND.

Tel: +44 (0)1738441040

Fax: +44 (0)1738 441042

E-mail: f.angus@bda-dentistry.org.uk

British Society of Paediatric Dentistry 50th Annual Scientific Meeting

Date: 11.09.02-14.09.02

Venue: University of Sheffield

Contact: Dr Helen Rodd, Department of

Child Dental Health, School of Clinical

Dentistry, Claremont Crescent, Sheffield,

S10 2TA.

Tel: +44 (0)114 2717885

Fax: +44 (0)114 2717843

E-mail: h.d.rodd@sheffield.ac.uk

Euopean Festival of Oral Science Joint

Meeting of the IADR

Date: 25.09.02-28.09.02

Venue: Cardiff, Wales

Contact: PEF Conference Secretariat

World Trade Center, Cardiff International

Arena, Mary Ann Street, Cardiff, CF10

2EQ. Wales.

Tel: +44 (0)2920 232322

E-mail:PEFOFIADR@global-

meeting.co.uk

Website: www.global-meeting.co.uk

\section{October 2002}

Faculty of General Dental Practitioners

National Study Day

Date: 18.10 .02

Venue: Didsbury, Manchester

Contact: Janet Bradshaw, lan Wood's

Dental Practice, 45, Northenden Road,

Sale, Cheshire, M33 2DL

Tel: +44 (0)1619736356

\section{Old enough to know better?}

It would be unlawful to exclude men from selling to a female market or specifically recruiting a white salesperson to pander to the prejudices of racist customers, why should age be any different? Should a dental practice be entitled to recuit a new dentist or nurse aged over 50 years old?

To comply with the EU directive, the UK must introduce comprehensive age discrimination laws by December 2006. The government is expected to publish its consultation paper by the end of the year, seeking views on when it should be legitimate to consider age in recruitment, training and promotion decisions. It will also invite responses on the use of mandatory retirement.

As with UK discrimination law on race and sex, the directive covers direct and indirect discrimination, harassment and victimisation. Discrimination will be lawful where it is objectively justified by a 'legitimate' aim and where the means of achieving that aim are appropriate and necessary.

\section{OBE Professor retires from Bristol}

Professor Chris Stephens OBE (pictured below) is retiring at the end of this academic year.

He has been a member of the academic staff at the University of Bristol Dental School for 30 years and is a leading figure in orthodontics and the use of computerbased information technology in the UK.

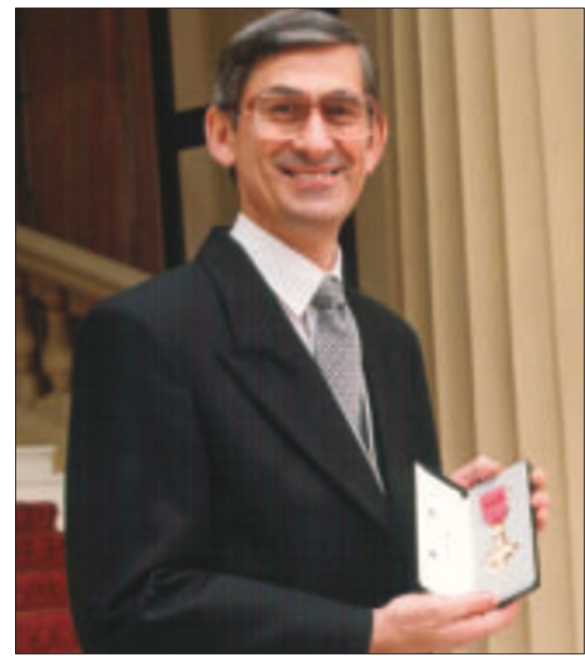

Professor Chris Stephens after being presented with an OBE.

\section{Dentists on the front line}

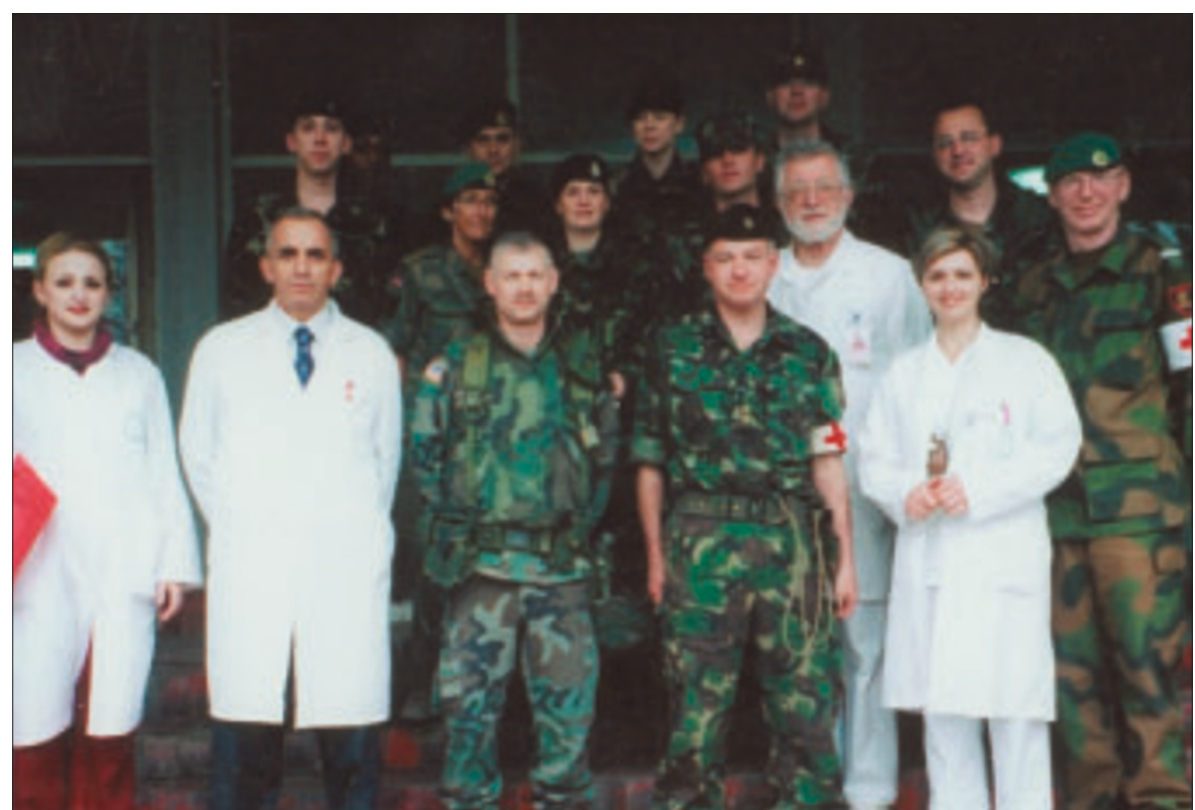

Army dentists support the British Forces across the world on every operation and exercise. The Royal Army Dental Corps was formed in 1921 and ever since has been a crucial part of the Army's support team. At the moment a number of dentists are in Kosovo in support of British Forces deployed as part of the NATO Kosovo Force (KFOR). The support staff such as the dentists, other medical staff and logistics forces ensure that the troops have the ability to carry out that mission. The dentists in Kosovo, based in the capital city, Pristina, also support other international personnel there which include other KFOR soldiers from around the world and the UN and charity organisations. Recently, a group of British, American and Norwegian dentists and hygienists serving in Kosovo were invited to visit the Dental School in Pristina, housed in the University of Pristina after accepting a special invitation from Professor Osman Sejfija, who heads the dental facility. 